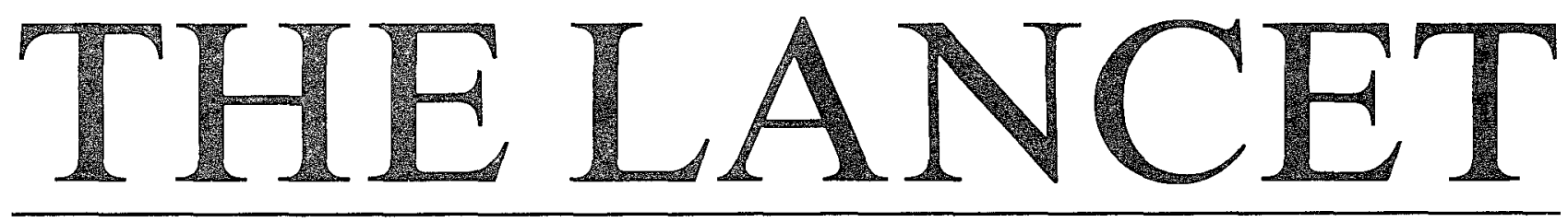

Venous thrombosis: a multicausal disease

F R Rosendaal

Reprinted from THE LANCET Saturday 3 April 1999 Vol. 353 No. 9159 Pages 1167-1173 


\title{
Venous thrombosis: a multicausal disease
}

\author{
FR Rosendaal
}

The risk factors for venous thrombosis differ from those for arterial vascular disease. During the past 5 years, knowledge about the aetiology of venous thrombosis has advanced with the discovery of several factors that contribute to the incidence of thrombosis, particularly the role of coagulation abnormalities. These abnormalities are common in the general population and therefore will be present simultaneously in some individuals. The resultant genegene and gene-environment interactions between risk factors are the key to the understanding of why a certain person develops thrombosis at a specific point in time.

Each year venous thrombosis occurs in about one in 1000 people in developed countries ${ }^{13}$ This disorder commonly manifests as deep-vein thrombosis of the leg, or, if embolisation occurs, as pulmonary embolism Thrombosis may rarely occur in other veins (cerebral sinus, and veins in the arms, retina, and mesentery) ${ }^{45}$ Major complications of venous thrombosis are a disabling post-thrombotic syndrome and acute death from a pulmonary embolism that occur in $20 \%{ }^{6}$ and $1-2 \%{ }^{2}$ of patients, respectively The incidence of thrombosis increases sharply with age, from 1 per 100000 people per year in childhood to nearly $1 \%$ per year in old age ${ }^{3}$

\section{Risk factors}

The risk factors for venous thrombosis differ from those for arterial disease-myocardial infarction, stroke, and atherogenic factors such as smoking, hypertension, or hyperlipidaemia do not increase the risk of venous thrombosis Virchow famously postulated three main causes of thrombosis stasis of the blood, changes in the vessel wall, and changes in the composition of the blood The known risk factors for venous thrombosis fall in the first group (stasis) and third group (composition changes), but nowadays a different classification is made into genetic and acquired risk factors

Acquired risk factors for thrombosis include immobilisation (including immobilisation in plaster casts), surgery, trauma, pregnancy, puerperium, lupus anticoagulant, malignant disease, and female hormones The first report of a family with an identified hereditary tendency to thrombosis (a deficiency of antithrombin, previously known as antuthrombin III) was made by Egeberg in $1965^{\circ}$ In the 1980s, protein C deficiency and protein $S$ deficiency were described in familial thrombophilia ${ }^{10}$ - thrombophilia being a tendency to venous thrombosis Over the past 5 years, several abnormalities in the clotting system that predispose to venous thrombosis have been discovered Resistance to actrvated protein C was first described in $1993^{11}$ and subsequently shown to be caused by a mutation in clotting factor $\mathrm{V}$, factor $\mathrm{V}$ Leiden ${ }^{12}$ Since protein $\mathrm{C}$, protein $\mathrm{S}$,

Lancet 1993, 353: 1167-73

See Commentary page 1118

Department of Clinical Epıdemiology and the Hemostasis and Thrombosis Research Center, Leiden University Medical Center, PO Box 9600, NL-2300 RC Leiden, Netherlands

(Prof F R Rosendaal MD) and antithrombin are the main natural inhibitors of the procoagulant system, a heterozygous deficiency of these proteins leads to excessive thrombin formation ${ }^{13}$

When factor $\mathrm{V}$ has a mutation at one of the cleavage sites for activated protein $C$ (factor $V_{R 506 Q}$ or factor $V$ Leiden), it is less sensitive to the natural anticoagulant protein C-protein S system-1e, there is resistance to activated protein $C$ This mutation leads to gain of function rather than loss of function Other abnormalities have been described that lead to gain in function and excesses in the procoagulant system A mutation in the 3'-untranslated region of the prothrombin (factor II) gene ( $G$ to $A$ at position 20210, PT20210A) is associated with increased plasma concentrations of prothrombin, and with an increased risk of thrombosis ${ }^{14}$ Similarly, high concentrations of clotting factor VIII are related to increased risk of thrombosis ${ }^{15}$ Concentrations of factor VIII are determined mostly by blood group, which accounts for the old observation of a relation between non-O blood groups and risk of thrombosis 1516

High concentrations of clotting factors are not caused by a mutation that has disrupted the normal sequence of a gene, as is the case with the deficiencies, but are the result of more subtle changes in the regulation of gene activity Several genetic loci influence the concentrations of clotting factors For example, for factor VIII there are at least three sets of genes involved The first are the genes that code for ABO blood group, since people with blood group $O$ have lower concentrations of factor VIII (and von Willebrand factor) than those with non-O blood groups The second are genes for von Willebrand factor, the carrier protein for factor VIII And finally, there is an unknown set of genes because even when blood group and von Willebrand factor are taken into account, there is still a familial tendency to aggregation of factor VIII concentrations, ${ }^{17}$ for which no cause has yet been found within the factor VIII gene ${ }^{18}$

Apart from a genetic make-up, variation may also be explained by acquired factors Obviously, anything that affects the organs where the clottung factors are produced may also affect concentrations of these factors (eg, liver disease, endothelial dysfunction), as may dietary intake of substrates and vitamins (vitamin $\mathrm{K}$ deficiency) There are also many other disorder that affect concentrations of clotting factors in more subtle ways, ${ }^{1920}$ and it is plausible that high concentrations of prothrombin and factor VIII reflect a mixture of genetic make-up and acquired factors Acquired factors may contribute to variations within and between individuals, which may underle differences in 


\begin{tabular}{|c|c|c|}
\hline Risk factor & $\begin{array}{l}\% \text { general } \\
\text { population }\end{array}$ & $\begin{array}{l}\% \text { patients with } \\
\text { thrombosis }\end{array}$ \\
\hline Protein C deficiency & 0204 & 3 \\
\hline Proteın S defıcıency & Not known & $1-2$ \\
\hline Antithrombin deficiency & 002 & 1 \\
\hline Factor V Leiden & 5 & 20 \\
\hline Prothrombin $20210 \mathrm{~A}$ & 2 & 6 \\
\hline High concentration of factor VIII $(>1500 \mathrm{IU} / \mathrm{L})$ & 11 & 25 \\
\hline Hyperhomocysteinaemia (>18 $5 \mu \mathrm{mol} / \mathrm{L}$ ) & 5 & 10 \\
\hline
\end{tabular}

Table 1 Prevalence of risk factors for thrombosis

risk between individuals or situations Even when a mutation is the cause of loss of function of the encoded protein, such as protein $\mathrm{C}$, protein $\mathrm{S}$, and antithrombin, plasma concentrations of these protens (in heterozygous deficiency) can vary This variation may be due to polymorphisms in the functional allele or to acquired factors such as age and hormones ${ }^{21} 22$

Finally, hyperhomocysteinaemia is an abnormality that has been associated with venous thrombosis in several studies $^{23}{ }^{26}$ and in a meta-analysis ${ }^{27}$ This abnormality is found in arterial and venous disease, ${ }^{28}$ but its cause is disputed in the absence of biological models Hyperhomocysteinaemia is a good example of abnormal plasma concentrations that result from genetic and acquired factors Mutations of cystathionine $\beta$-synthase or methylene tetrahydrofolate reductase (MTHFR) lead to increased concentrations of homocysteine Most individuals with hyperhomocysteinaemia, however, do not carry e1ther genetic variant, but have impaired methronine metabolism, so the hyperhomocysteinaemia ${ }^{15}$ is caused by insufficient dietary intake of folic acid and vitamins B6 or B12 ${ }^{29}$

\section{Prevalence and risk estimates}

The impact of a risk factor is a function of its prevalence and relative risk Table 1 shows the prevalence of various risk factors among white people in the general population of developed countries and among patients with venous thrombosis ${ }^{143035}$ Deficiencies of protein $C$, protein $S$, and antithrombin are rare, even among patients with thrombosis Since these deficiencies are rare, the 11sk is not easy to assess and the risk estimates vary A fair estimate seems to be that all the deficiencies increase the risk of deep-vein thrombosis by about ten-fold ${ }^{30}{ }^{36}$ Four abnormalities that have been discovered or associated with venous thrombosis in the past 5 years are far more common in the general population actuvated protein $C$ resistance, prothrombin 20210A, high concentrations of factor VIII, and hyperhomocystemaemua Activated protein resistance, caused by factor $V$ Leiden, occurs in $5 \%$ of the population ${ }^{34}{ }^{37}$ The prevalence estimates vary because of regional differences and are high (up to 15\%) in southern Sweden and the middle-east Factor V Leiden is restricted to white people ${ }^{37}$ Among patrents with venous thrombosis, factor V Leiden occurs in $20 \%{ }^{3438}$ and seems to be a risk factor of much the same strength as the deficiencies of coagulation inhibitors, increasing the risk by about eight-fold among heterozygous carriers ${ }^{34}$

Prothrombin 20210A is found in $2 \%$ of the population worldwide, again with regional differences ${ }^{39}$ Among patients with thrombosis, prothrombin 20210A has been found in $6 \%$, and it seems to be a mild risk factor, increasing the risk by two-fold to three-fold ${ }^{14}$ Until now, the mutation has been reported mainly in white people ${ }^{39}$

The prevalence of high concentrations of factor VIII and hyperhomocysteinaemia depend on the cut-off values that are applied Factor VIII concentrations that exceed
$1500 \mathrm{IU} / \mathrm{L}$ ( $150 \%$ of normal) have been found in $11 \%$ of the general population, and $25 \%$ of patients with thrombosis ${ }^{15}$ Such high concentrations compared with those below 1000 IU/L were associated with a six-fold increased risk of thrombosis ${ }^{15}$ Because of the high prevalence and relative risk, high concentrations of factor VIII may be responsible for most thrombotic events of the abnormalities listed in table 1 Concentrations of homocysteme greater than $185 \mu \mathrm{mol} / \mathrm{L}$ were found in $5 \%$ of the general population in the Netherlands, and $10 \%$ of the Italan population ${ }^{25} 26$ Compared with patients whose concentrations were below $185 \mu \mathrm{mol} / \mathrm{L}$, people with concentrations above $185 \mu \mathrm{mol} / \mathrm{L}$ had a 25 -fold increased risk of thrombosis, for concentrations above $20 \mu \mathrm{mol} / \mathrm{L}$, the risk increased by three-fold to four-fold

\section{Thrombosis as a multicausal disease}

Thrombosis manifests itself as a multicausal disease most clearly in children In the rare event of thrombosis in children, several acquired and genetic risk factors are usually present simultaneously Not only is it rare to find children with thrombosis without any risk factor, but many have three or four risk factors In $25-30 \%$ of children with thrombosis, deficiencies of protein $\mathrm{C}$, protein $\mathrm{S}$, or antithrombin have been reported, but thrombosis did not develop untl other risk factors were present, such as intravenous lines or major illness ${ }^{4041}$

Thrombosis is also a multicausal disease in adults since many risk factors are common in the general population, such as factor V Leiden, prothrombin 20210A, high concentrations of factor VIII, and hyperhomocysteinaemia, which frequently occur together in one individual The acquired risk factors, such as pregnancy, puerperium, use of oral contraceptives, and immobilisation, also affect many people, so a combination of risk factors in one person is common Indeed, multiple risk factors are a prerequisite for thrombosis to develop

\section{Selection and interaction}

Among families with a tendency to thrombosis, the prevalence of thrombogenic abnormalities is much higher than among the unselected "average" patrent with thrombosis who is described in table 1 In thrombophilic families, deficiencies of the main coagulation inhibitors occur in $15 \%$, prothrombin $20210 \mathrm{~A}$ in nearly $20 \%$, and factor $\mathrm{V}$ Leiden in $40-60 \%$ The risk of thrombosis is also higher in members of these families than among other individuals with similar defects ${ }^{12334^{7}-47}$

Comparison of patients with the same defect shows that the way in which they were identified seems to be the most important determinant of their individual thrombotic risk The mean age at first thrombosis for patients from thrombophilic families is much younger than for consecutive patients with thrombosis, irrespective of the underlying defect (table 2) ${ }^{18}$ Remarkably, thrombosis even occurs at an early age in thrombophilic families with no identifiable defect ${ }^{48}$

\begin{tabular}{lll}
\hline Risk factor & Age (years) at first thrombosis & \\
\cline { 2 - 3 } & $\begin{array}{l}\text { Pataients from thrombophilıc } \\
\text { familes }(n=78)\end{array}$ & $\begin{array}{l}\text { Consecutive unselected } \\
\text { patıents }(n=105)\end{array}$ \\
\cline { 2 - 2 } & 31 & 47 \\
\hline Protein C deficiency & 29 & 43 \\
Factor V Leiden & 34 & 46 \\
No defect found & &
\end{tabular}

Data are from Lensen and colleagues ${ }^{46}$

Table 2 Age at first thrombosis by origin of patient 
The most likely explanation for this observation is that, although thrombosis is multicausal, familial thrombophilia is multigenic-1e, in each of the families there are several genetic defects For example, with the protein $\mathrm{C}$ families registered at the Leiden clinic, a high risk of thrombosis was reported among individuals with protein $\mathrm{C}$ deficiency in these families, compared with relatives without the deficiency (figure 1) ${ }^{16}$ For relatives with protein $C$ deficiency, $50 \%$ had thrombosis at age 50 years, which suggested a very high risk of thrombosis associated with protein C deficiency Several years later, these families were investigated for factor $\mathrm{V}$ Leiden, which turned out to be common in the families The risk of thrombosis was much higher for those family members who carried both defects than for those who carried protein $\mathrm{C}$ deficiency or factor $\mathrm{V}$ Leiden (figure 1) ${ }^{49}$ With this knowledge of the additional risk factor in these families, it became clear that the risk of thrombosis associated with protein $\mathrm{C}$ deficiency had initially been overestumated

\section{Gene-gene interaction}

The high risk of thrombosis associated with the combination of protein $\mathrm{C}$ deficiency and factor V Leiden is an example of gene-gene interaction Similar findings have been documented for familes with protein $S$ deficiency, ${ }^{50}$ antithrombin deficiency, ${ }^{3}$ and prothrombin 20210A, ${ }^{5}$ factor V Leiden is common in these families, and those with a combined defect have a high risk of thrombosis These findings all suggest that the risk of abnormalities will be an overestimate if it is derived from family studies additional defects explain individual variation within and between families

A special type of gene-gene interaction is present in homozygous disease Homo/ygous protein $\mathrm{C}$ and protein $\mathrm{S}$ deficiency are rare but devastating disoiders, with severe thrombosis (purpura fulminans) orcuiring shortly after burth ${ }^{354}$ Homozygous antithrombin deficiency may not even be compatible with life 5 Because of the low prevalence of these deficiencies, homozygous patients are rare and are commonly the tesult of consanguintty Homozygous carriers of factor $\mathrm{V}$ Leiden are more common ( 1 per 5000 people) ${ }^{31}$ The thrombotic risk for individuals homozygous for factor $V$ Leiden is high (80-fold increased ws non carriers), but not as high is for people with homozygous deficiencies of the coagulation inhibitors most patients do not develop thrombosis until adulthood and may ressain symptomfree until old age ${ }^{345}$ This situation also seems to be the case for homozygous calriers of prothrombin $20210 \mathrm{~A},{ }^{57}$ the explanation for the absence of a greatly increased risk, as compared with that for homozygous deficiencies of the coagulation inhibitors, is that these are mutations that lead to gain rather than loss of function

\section{Gene-environment interaction}

Since some of the recently discovered genetic abnormalities are common, as are several acquired risk factors, the joint effects of such factors on risk of thrombosis warrants investigation Clear indications of synergistic effects come fiom studies in thrombophilic families, where high risks werc found in pregnancy and the puerperium, and during use of oral contraceptives, for women with deficiencies of protein $C$, protein $S$, or antithrombin ${ }^{5586}$ In several series of unselected women

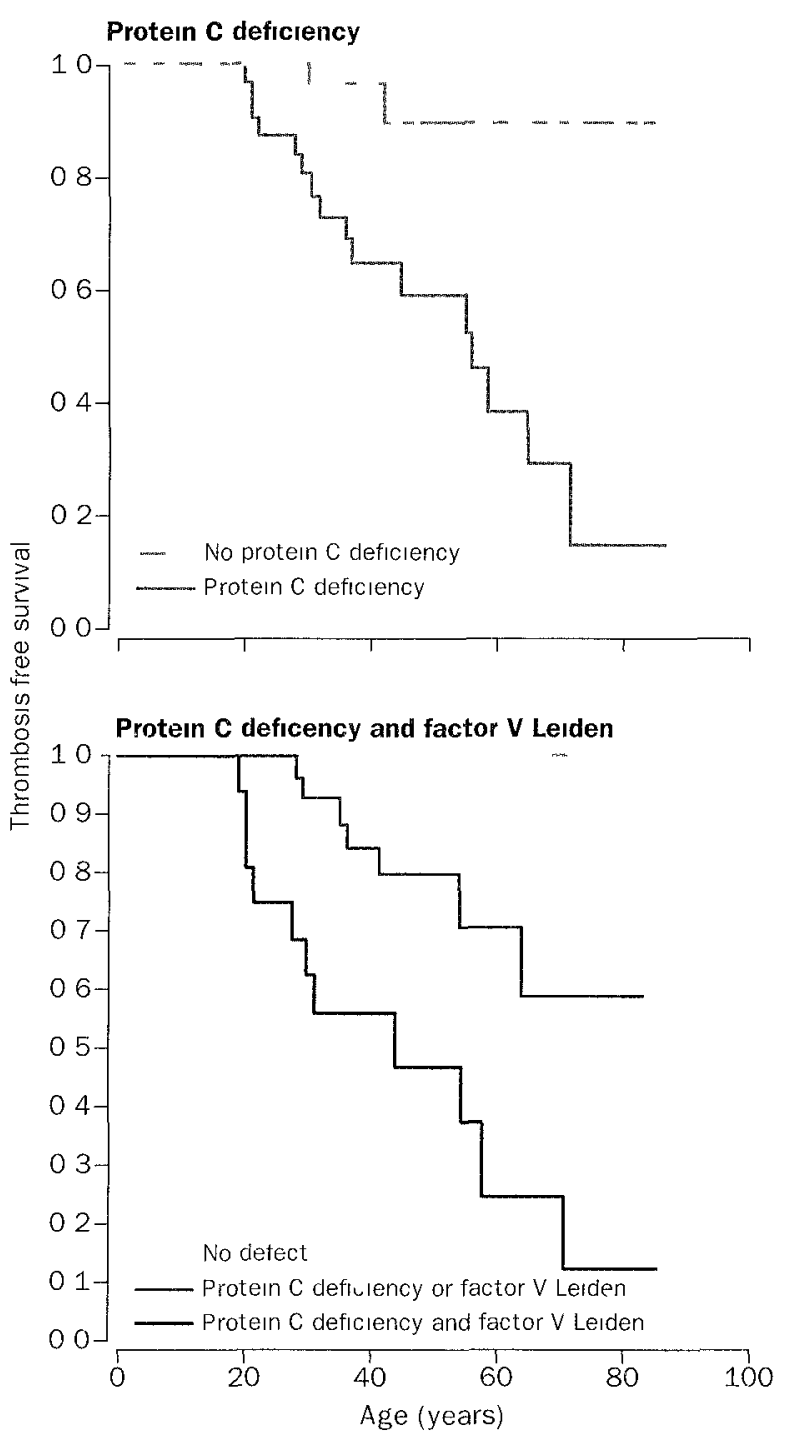

Figure 1 Thrombosis-free survival in families with thrombophilıa due to protein $\mathrm{C}$ deficiency (proband excluded)

with thombosis during pregnancy, factor V Leiden was more common than in the generdl population ${ }^{3}$ The frequency of factor $\mathrm{V}$ Leiden among these women varied widely betwecn studies, fiom $8 \%$ in Scotland to $5060 \%$ in Sweden, ${ }^{3}$ ' which partly reflects geographical differences in the population prevalence of factor $\mathrm{V}$ Leiden These data suggest that a substantial part of pregnancy-ielated thrombosis results from concomitant abnormaliues in the haemostatic system

Among unselected pautnts, a synergistic effect has been shown for factor $\mathrm{V}$ Leiden and use of oral contraceptrves the estimated baseline risk of thrombosis for non-carriers who do not use oral contraceptives was 08 per 10000 people per ytar The annual risk for women with factor $\mathrm{V}$ Leiden who did not use oral cont1aceptives was 57 per 10000 people (relatıve rusk 69 ), that for women who used oral contraceptives but did not carry factor $V$ Leiden was 30 per 10000 women (relative risk 37), and that for women with factor $\mathrm{V}$ Leiden who used oral contraceptives was 285 per 10000 people (relative risk 347$)^{7}$

For cerebral sinus thrombosis, increased risk of thrombosis has been 1eported for thrombophilic defects The combination of protein $\mathrm{C}$ deficiency, factor $\mathrm{V}$ 

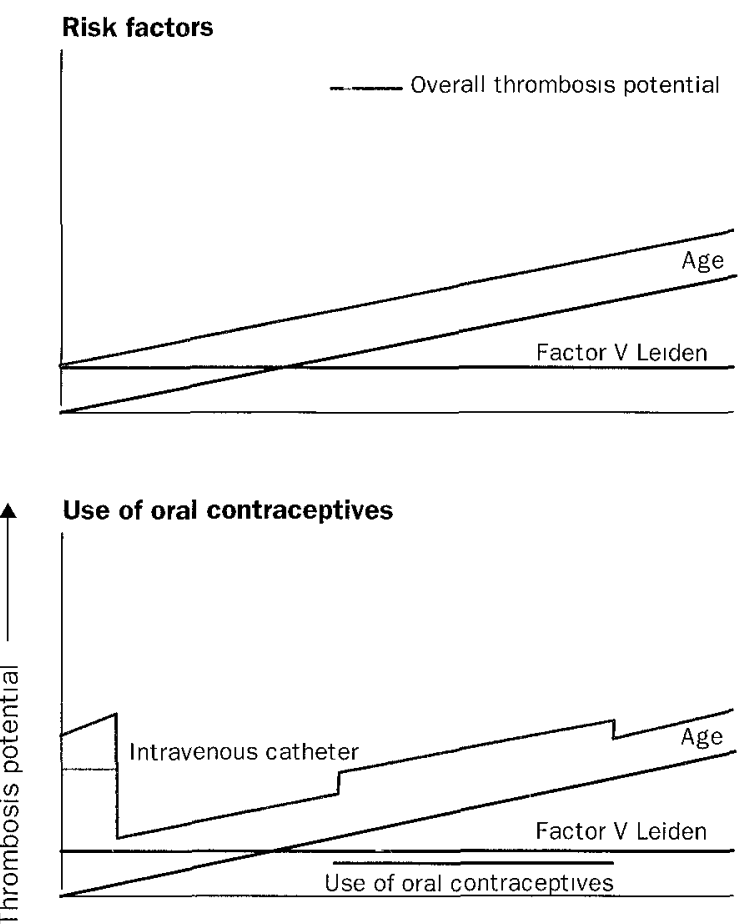

Skiing accident leads to immobilisation at age $\mathbf{3 0}$
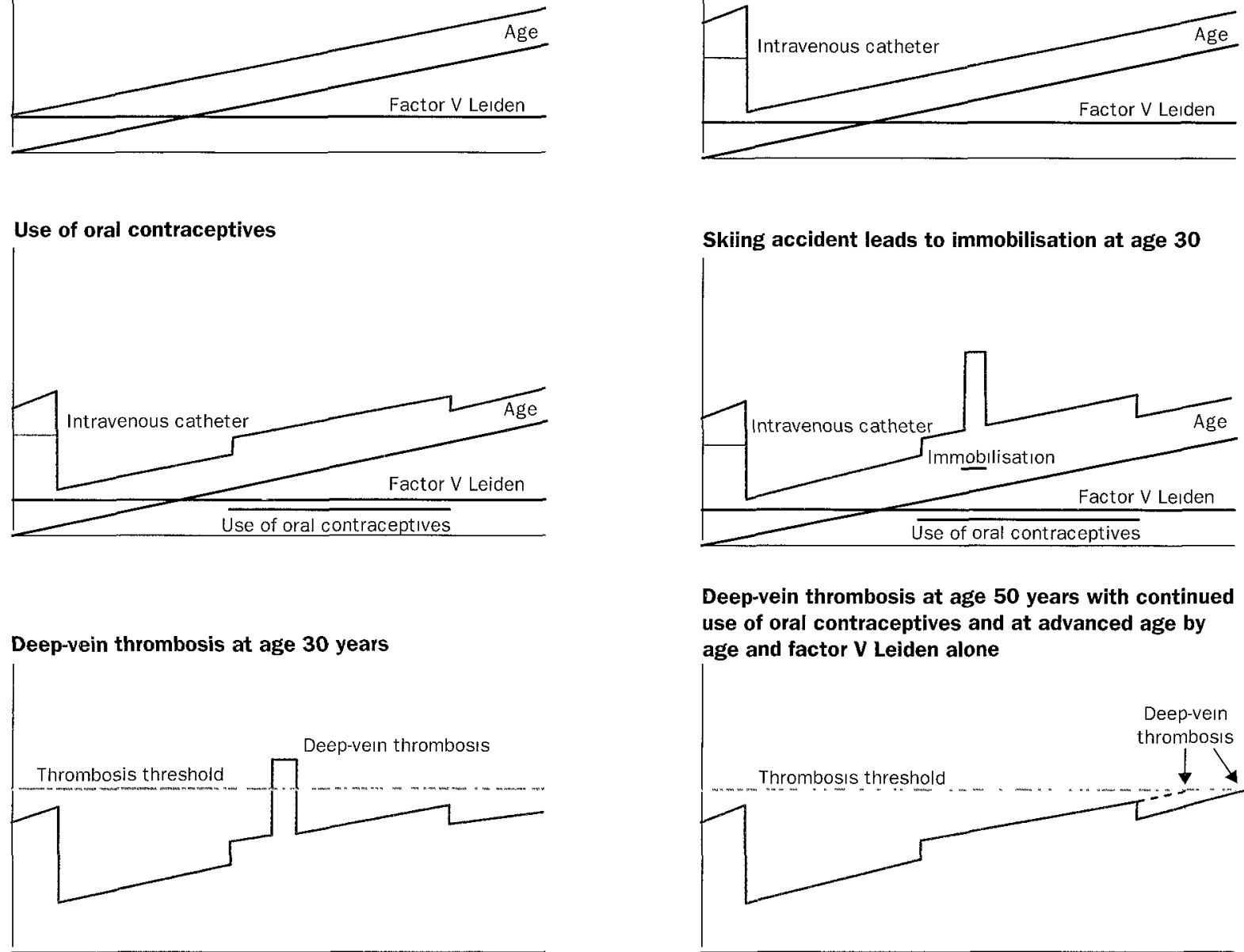

Deep-vein thrombosis at age 50 years with continued use of oral contraceptives and at advanced age by age and factor $V$ Leiden alone

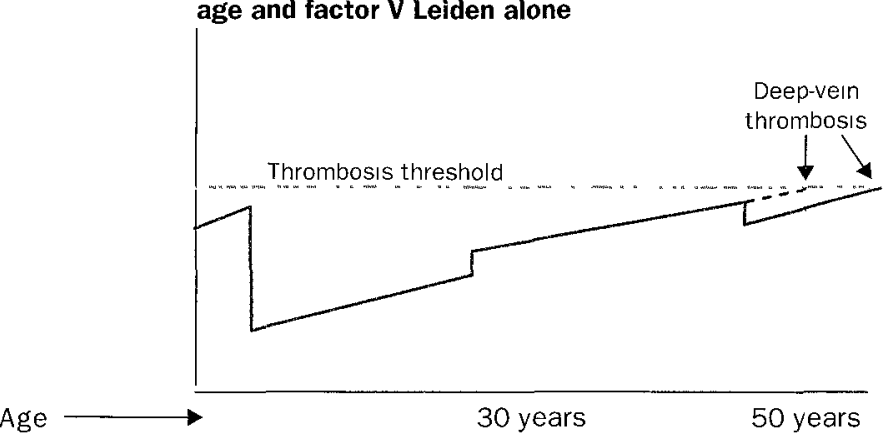

Figure 2: Models of thrombosis risk

In each panel, the figure shows the thrombosis (black) potentıal of each risk factor present durıng an individual's life and the resultant thrombosis potential (red).

Leiden, or prothrombin 20210A, and use of oral contraceptive led to a 30 -fold to 150 -fold increased risk, compared with that for women who did not use oral contraceptives and did not have such a defect. ${ }^{68,69}$ These combined risks are much higher than the individual risk conferred by use of oral contraceptives or a thrombophilic defect. ${ }^{68,69}$

For many combinations of risk factors, there are no reliable estimates of risk and conclusions are made on the basis of only one or a few studies. For the more common clotting abnormalities and for combined acquired risk factors (environment-environment interaction), results are likely to be forthcoming.

\section{Models of thrombosis risk}

When the first coagulation defects that underlie thrombophilia were discovered, such as, deficiencies of antithrombin, protein $\mathrm{C}$, and protein $\mathrm{S}$, thrombosis was considered a single-gene defect. ${ }^{70,71}$ Since the first families studied were those with the most pronounced thrombophilia, for reasons explained above, it is understandable that for some time one defect was thought sufficient for thrombosis. Of course, the risk in these families was so high because they harboured several defects. Since not every person with a deficiency developed thrombosis, this single-gene model was abandoned..$^{72,73} \mathrm{~A}$ subsequent model was that of familial thrombophilia as a multiple-gene disorder that is analogous to the multistage or multiple-hit theories for cancer. ${ }^{74}$ Support for this view can be found in families with thrombophilia who frequently harbour several known defects, and possibly, and most likely, unidentified defects as well. However, although this model is an improvement on the single-gene concept, it is not all encompassing and makes an artificial difference between thrombophilia and thrombosis. Moreover, this model ignores acquired risk factors. The multiple-gene model seems appropriate only for homozygous deficiencies of protein $\mathrm{C}$ and protein $\mathrm{S}$, in which thrombosis occurs immediately after birth. In all other instances, even when the risk of thrombosis is high, as in individuals with homozygous factor $\mathrm{V}$ Leiden or with both factor $\mathrm{V}$ 


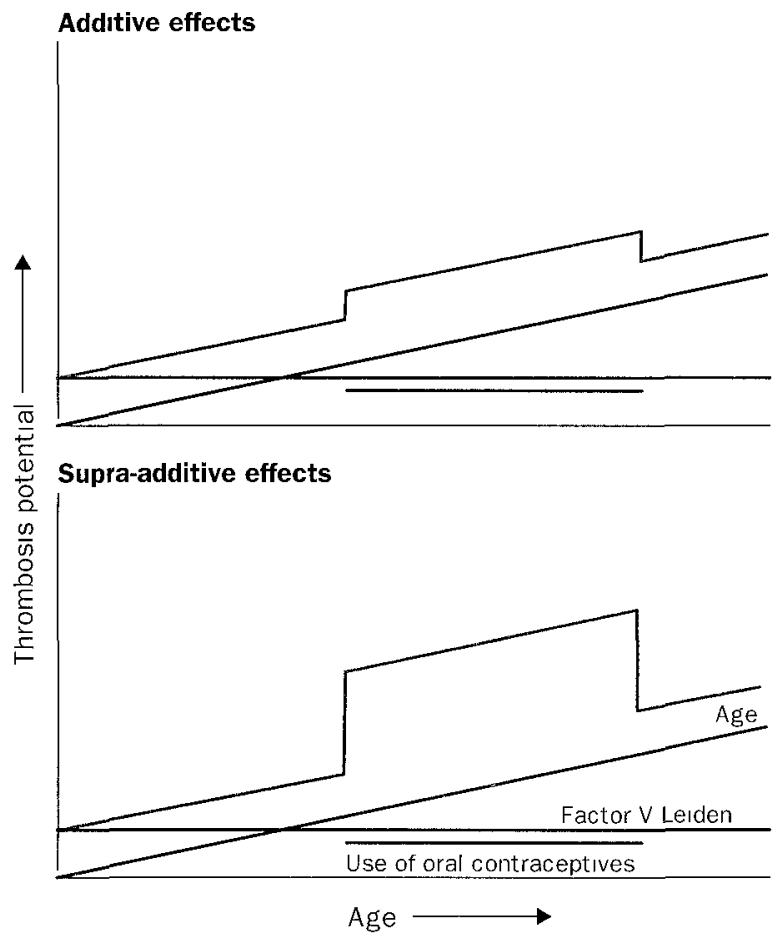

Figure 3 Models of thrombosis risk with different interactions between factor $\mathrm{V}$ Leiden and use of oral contraceptive

Top the thrombosis potentials add to form the resultant potential Bottom effect of the combination is supra additive

Leiden and protein $\mathrm{C}$ deficiency, the question arises of why one person develops thrombosis while another does not, and why an individual develops thrombosis at a certain age and not before

Even a multicausal model that incorporates genetic and acquired risk factors does not readily explain why the same number of risk factors causes thrombosis in one person and not in another, or even why the same set of risk factors does not cause thrombosis in children but causes this disorder in olde1 people Thus, there is a need for a dynamic age-dependent model that allows for various forms of interaction of risk factors (eg, additive effects or synergism) Figure 2 shows such a model Here, the assumption is that each risk factor adds to the risk, which can be called an individual's thrombosis potential For each part of figure 2, the black lines show the thrombosis potential of each individual risk tactor for a particular woman, and the red line her total thrombosis potential The horizontal axis shows time (the age of the individual) The model is dynamic, bccause we assume that the thrombosis potential is age-dependent, which is based on the observation that more 11sk factors are required in children than in adults and that the incidence of thrombosis increases with age So, age itself seems to increase the thrombosis potential, probably as the result of wear-and-tear on the vessels and their valves, or of such factors as decreased mobility Figure 2 follows an individual with factor $V$ Leiden through her life The figure starts with the risk factors age and factor $V$ Leiden and in red the thrombosis potential when no other risk factors are encountered throughout life Then a major disease during childhood is introduced that required an intravenous line, which is a factor with a high thrombosis potential, and so there is a short period with a high thrombosis potential, after which the thrombosis potential reverts to its previous level Then, between age 20-40 years she started to take oral contraceptives, which have an intermediate thrombosis potential and alter the overall thrombosis potential for 20 years Finally, at age 30 , she had a plaster cast after a skinng injury, which conferred a high thrombosis potential for a short time The overall lifetime thrombosis potential now has a complicated form and will, because of the specific set of risk factors at a certain age, exceed the thrombosis threshold (in green), and lead to deep-vein thrombosis at age 30 The same set of risk factors (factor V Leiden, oral contraceptives, plaster cast) would not have caused thrombosis at age 20 Sumlarly, if she had not had the plaster casts, but contınued to use the pill, thrombosis would have occurred around age 50 And at an older age, the mere effect of age and factor $\mathrm{V}$ Leiden would have been sufficient to lead to thrombosis

\section{Interaction}

Interaction occurs when two risk factors in combination produce an effect that exceeds the sum of their separate effects It has been shown that different hypothetical biological mechanisms may lead to diverse risk profiles ${ }^{75}$ Interaction 1s, therefore, defined in numerical terms, and not in terms of biological mechanism, and the presence or absence of interaction does not allow conclusions about biological mechanisms, even though the finding of interaction may prompt research into mechanisms ${ }^{76}$ It $1 \mathrm{~s}$ sufficient to define interaction on an additive scale- 1 e, whether the combination of risk factors has greater effect than the sum of the effects of separate risk factors-as opposed to a definition on a multiplicative scale, in which the relative risk of the combination needs to exceed the product of the separate relative risks ${ }^{31}$ However, since interaction is only a numerical concept, it is more relevant to estimate the magnitude of the combined effect of two factors, rather than to attempt to decide whether two factors display synergism or not, which is a theoretical issue without clear biological meaning

The model outlined in figure 2 can be extended to allow for a specific set of risk factors that yield higher thrombosis potentials together than separately, or in the presence of other factors Figure 2 shows models where all factors are assumed to behave in an additive manner-1e, without interaction Figure 3 shows that when factors have supra-additive effects, for example, factor V Leiden and use of oral contraceptives, this effect can be built into the model, and results in much higher thrombosis potentral

\section{Conclusion}

Thrombosis is a disease in which genetic and acquired risk factors interact dynamically A time-dependent model that incorporates interaction of risk factors is valuable to explain why thrombosis occurs in one person at a specific time Such a model will primarly be useful to shape thinking about the aetiology of thrombosis Theoretically, this model will guide us to be able to provide individual risk estumates and set gurdelines for prevention and prophylaxis This process will require much additional knowledge first, of the combined effect of all possible combinations of risk factors, and, second, of the dynamic interplay between genes and environment in determining concentrations of clotting factors and coagulation homoeostasis 
Parts of this paper were presented previously at the President's Symposium of the International Congress of Hemostasis and Thrombosis, June 8 , 1997, in Florence

\section{References}

1 Nordstrom M, Lundblad B, Bergquist D, Kjellstrom T A prospective study of the incidence of deep-vein thrombosis with a defined urban population f Intern Med 1992, 232: 155-60

2 Anderson FA, Wheeler HB, Goldberg RJ, et al A population based perspective of the hospital incidence and case-fatality rates of deep vein thrombosis and pulmonary embolism The Worcester DVT study Arch Intern Med 1991, 151: 933-38

3 Rosendaal FR Thrombosis in the young epidemiology and nsk factors, a focus on venous thrombosis Thromb Haemost 1997, 78: 1-6

4 Carter CJ The natural history and epidemiology of venous thrombosis Prog Cardiovasc Dts 1994, 36: 423-38

5 Thomas DP Pathogenesis of venous thombosis In Bloom AL Forbes CD, Thomas DP, Tuddenham EGD, eds Haemostasıs and thrombosis New York Churchill-Luvingstone, $1994 \quad 1335-47$

6 Brandıes DP, Buller HR, Heıboer $\mathrm{H}$, et al Randomised trial of effect of compression stockings in patients with symptomatic proximal-vein thrombosis Lancet 1997, 349: 759-62

7 Virchow R Phlogose und Thrombose $1 \mathrm{~m}$ Gefassystem In Gesammelte Abhandlungen zur Wissenschaftlichen Medizin Frankfurt Staatsdruckere 1,1856

8 Egeberg $O$ Inherited antithrombin deficiency causing thrombophilia Thromb Diath Haemorrh 1965, 13: 516-30

9 Griffin JH, Evatt B, Zimmerman TS, Kletss AJ, Wideman C Deficiency of protein $\mathrm{C}$ in congenital thrombotac disease $\mathcal{F}$ Chn Invest 1981, 68: $1370-73$

10 Schwartz HP, Fischer M, Hopmeser P, Batard MA, Griffin JH Plasma protein $S$ deficiency in familial thrombotic disease Blood 1984, 64: $1297-1300$

11 Dahlback B, Carlsson $M$, Svensson PJ Familal thrombophlia due to a previously unrecognised mechanism characterized by poor anticoagulant response to activated protein $C$ prediction of a cofactor to activated protein C Proc Natl Acad Sct USA 1993, 90: 1004-08

12 Bertina RM, Koeleman RPC, Koster $T$, et al Mutation in blood coagulation factor $\mathrm{V}$ associated with resistance to activated protein $\mathrm{C}$ Nature 1994, 369: 64-67

13 Mannucc PM, Tripodi A, Botasso B, et al Markers of procoagulant imbalance in patients with inherited thrombophilic syndromes Thromb Haemost 1992, 67: 200-02

14 Poort SR, Rosendaal FR, Reitsma PH, Bertuna RM A common genetic variation in the 3'-untranslated region of the prothrombin gene is associated with elevated plasma prothrombin levels and an increase in venous thrombosis Blood 1996, 88: 3698-703

15 Koster T, Blann AD, Briet E, Vandenbrouke JP, Rosendaal FR Role of clottung factor VIII in effect of von Wlllebrand factor on occurrence of deep-vein thrombosis Lancet 1995, 345: 152-55

16 Jick H, Slone D, Westerholm B, et al Venous thromboembolic disease and ABO blood type Lancet 1969,1 539-42

17 Kamphuisen PW, Houwing-Dustermaat J, van Houwelingen JC, et al Famulal clustering of factor VIII and von Willebrand factor levels Thromb Haemost 1998, 79: 323-27

18 Mansvelt EPG, Laffan M, McVey JH, Tuddenham EGD Analysis of the F8 gene in individuals with high plasma factor VIII $C$ levels and associated venous thrombosis Thromb Haemost 1998, 80: 561-65

19 Balleisen L, Bailey J, Epping PH, Schulte H, van de Loo J Epidemiological study on factor VII, factor VIII and fibrinogen in an industrial population I Baseline data on the relation to age, gender, body-weight, smoking, alcohol, pill-using, and menopause Thromb Haemost 1985, 54: 475-79

20 Balleisen L, Assman G, Barley J, Epping PH, Schulte H, van de Loo J Epidemiological study on factor VII, factor VIII and fibrinogen in an industrial population II Basehne data on the relation of blood pressure, blood glucose, uric acid, and lipid fractions Thromb Haemost 1985, 54: 721-23

21 Lowe GD, Rumley A, Woodward M, et al Epidemology of coagulation factors, inhibitors and actuvation markers the Third Glasgow MONICA Survey I Illustrative reference ranges by age, sex, and hormone use Br f Haematol 1997, 97: 775-84

22 Bloemenkamp KWM, Rosendaal FR, Helmerhorst FM, Koster T, Bertina RM, Vandenbroucke JP Hemostatic effects of oral contraceptives in women who developed deep-vein thrombosis while using oral contraceptives Thromb Haemost 1998, 80: 382-87

23 Bienvenu T, Ankn A, Chadefaux B, Kamoun P Plasma homocystein assay in the exploration of thrombosis in young subjects Presse Medicale 1991, 20: 985-88

24 Falcon CR, Cattaneo M, Panzer D, Martinell I, Mannuccı PM High prevalence of hyperhomocyst(e)memia in patients with juvenile venous thrombosis Artenoscler Thromb 1994, 14: 1080-83
25 Simını P, Prandon P, Burlına A, et al Hyperhomocystememıa and deep-vein thrombosis a case-control study Thromb Haemost 1996, 76: 883-86

26 Den Heijer M, Koster T, Blom HJ, et al Hyperhomocystemema as a nsk factor for deep-ven thrombosis $N$ Engl F Med 1996, 334: 759-62

27 Den Heıer M, Rosendaal FR, Blom HJ, Gernts WBJ, Bos GMJ Hyperhomocystennemia and venous thrombosis a meta-analysis Thromb Haemost 1998, 80: 874-77

28 Fermo I, D'Angelo SV, Paronı R, Mazzola G, Calon G, D'Angelo A Prevalence of moderate hyperhomocysteinemia in patients with earlyonset venous and arterial occlusive disease Ann Intern Med 1995, 123 : $747-53$

29 Ubbink JB, Vermaak WJ, Van der Merwe A, Becker PJ Vitamın B12, vitamin $B 6$, and folate nutritional status in men with hyperhomocystememı Am $\mathcal{J}$ Clin Nutr 1993, 57: 47-53

30 Rosendaal FR Risk factors for venous thrombosis prevalence, risk and interaction Semin Hematol 1997, 34: 171-87

31 Tait RC, Walker ID, Reitsma PH, et al Prevalence of proten C deficiency in the healthy population Thromb Haemost 1995, 73; 87-93

32 Tatt RC, Walker ID, Perry DJ, et al Prevalence of antithrombin deficiency in the healthy population $\mathrm{Br} f$ Haematol 1994, 87: 106-12

33 Miletich J, Sherman L, Broze G Absence of thrombosis in subjects with heterozygous protein C deficiency $N$ Engl 7 Med 1987, 317: 991-96

34 Rosendaal FR, Koster T, Vandenbroucke JP, Reitsma PH High nisk of thrombosis in patients homozygous for factor $V$ Leiden (actuvated protein C resistance) Blood 1995, 85: 1504-08

35 Koster $T$, Rosendaal FR, Briet E, et al Protein C deficiency in a controlled senes of unselected outpatients an infrequent but clear risk factor for venous thrombosis (Le1den Thrombophila Study) Blood 1995, 85: 2756-61

36 Lane DA, Mannuccı PM, Bauer KA, et al Inherited thrombophilia part 1 Thromb Haemost 1996, 76: 651-62

37 Rees DC, Cox M, Clegg JB World distribution of factor V Leiden Lancet 1995, 346: 1133-34

38 Koster T, Rosendaal FR, De Ronde H, Brnet E, Vandenbroucke JP, Bertina RM Venous thrombosis due to a poor anticoagulant response to activated protein C Leiden Thrombophlia Study Lancet 1993, 342: 1503-06

39 Rosendaal FR, Doggen CJM, Zivelin A, et al Geographic distribution of the $20210 \mathrm{G}$ to A prothrombin variant Thromb Haemost 1998, 79: 706-08

40 Andrew $M$, Dand $M$, Adams $M$, et al Venous thromboembolic complications (VTE) in children first analyses of the Canadian registry Blood 1994, 83: 1251-57

41 Nuss R, Hays T, Manco-Johnson M Childhood thrombosis Pedatncs 1995, 96: 291-94

42 Tabernero MD, Tomas JF, Alberca I, Orfao A, Lopez Borrasca A, Vicente $V$ Incidence and clinical characteristics of hereditary disorders associated with venous thrombosis Am $\mathcal{F}$ Hematol 1991, 36: 249-54

43 Gnffin JH, Evatt B, Wideman C, Fernandez JA Antıcoagulant protein $C$ pathway defective in a majority of thrombophilic patients Blood 1993, 82: 1989-93

44 Scharrer I, Hach-Wunderle V, Heyland $\mathrm{H}$, Kuhn $\mathrm{C}$ Incidence of defective $t-P A$ release in 158 unrelated young patients with venous thrombosis in comparison to PC-, PS-, AT III-, fibrnogen- and plasminogen deficiency Thromb Haemost 1987, 58: 72

45 Ben Tal O, Zivelin A, Seligsohn U The relative frequency of hereditary thrombotic disorders among 107 patients with thrombophilia in Israel Thromb Haemost 1989, 61: 50-54

46 Allaart CF, Poort SR, Rosendaal FR, Reitsma PH, Bertina RM, Briet $\mathrm{E}$ Increased nsk of venous thrombosis in carriers of protein $\mathrm{C}$ deficiency defect Lancet 1993, 341: 134-38

47 Tsuda S, Reitsma P, Mileuch J Molecular defects causing heterozygous protein $C$ deficiency in three asymptomatic kundreds Thromb Haemost 1991, 65: 647

48 Lensen RPM, Rosendaal FR, Koster T, et al Apparent different thrombotic tendency in patients with factor $V$ Leiden and protein $C$ deficuency due to selection of patients Blood 1996, 88: 4205-08

49 Koeleman BPC, Reitsma PH, Allaart CF, Bertuna RM APC-resıstance as an additional nsk factor for thrombosis in protein $\mathrm{C}$ deficient famultes Blood 1994, 84: 1031-35

50 Zoller B, Berntsdotter A, Garcia de Frutos P, Dahiback B Resistance to activated protein $\mathrm{C}$ as an additional genetic nsk factor in hereditary deficiency of protem S Blood 1995, 85: 3518-23

51 Van Boven HH, Restsma PH, Rosendaal FR, et al Factor V Leiden (FV R506Q) in familes with inherited antithrombin deficiency Thromb Haemost 1996, 75: 417-21

52 Makris M, Preston FE, Beauchamp NJ, et al Co-1nhentance of the $20210 \mathrm{~A}$ allele of the prothrombin gene increases the risk of thrombosis in subjects with familal thrombophilia Thromb Haemost 1997, $1701426-29$ 
53 Branson $\mathrm{HE}$, Marble R, Katz J, Griffin JH Inherted protein C deficiency and coumarn-responsive chronic relapsing purpura fulminans in a newborn Lancet 1983, 1116568

54 Mahasandana C, Suvatte V, Chuansumrt A, et al Homozygous protein $S$ deficiency in an infant with purpura fulminans $\mathcal{F}$ Pediatr 1990, 117: 750-53

55 Hakten M, Deniz U, Ozbag G, Ulutm ON Two cases of homozygous antuthrombin III deficiency in a family with congenital deficiency of ATIII In Senzinger $\mathrm{H}$, Vinazzer $\mathrm{H}$, eds Thrombosis and haemorrhagic disorders Wurzberg Schmitt und Meyer GmbH, 1989 $177-81$

56 Runtelen C, Mannhalter C, Ireland H, et al Oral contraceptuves enhance the risk of clinical manifestation of venous thrombosis at a young age in females homozygous for factor V Leiden $\mathrm{Br} f$ Haematol 1996, 93: 487-90

57 Kyrle PA, Mannhalter C, Beguin S, et al Clintcal studies and thrombin generation in patients homozygous or heterozygous for the G20210A mutation in the prothrombin gene Anemoscler Thromb Vasc Biol 1998, 18: $1287-91$

58 Conard J, Horellou MH, Van Dreden P, Lecompte T, Samama M Thrombosis and pregnancy in congenital deficiencies in AT III, protein C or protein S study of 78 women Thromb Haemost 1990, 63: 319-20

59 Pabınger I, Schneider B, and the GTH Study Group Thrombotic risk of women with hereditary antithrombin III-, protein $C$ and protein Sdeficiency taking oral contraceptive medication Thromb Haemost 1994 71: $548-52$

60 De Stefano V, Leone G, Mastrangelo S, et al Thrombosis during pregnancy and surgery in patients with congenital deficiency of antithrombin III, protein C, protein S Thromb Haemost 1995, 74: 793-94

61 Hellgren M, Tengborn L, Abildgaard U Pregnancy in women with congenital antithrombin III deficiency expenence of treatment with heparın and antithrombin Gynecol Obstet Invest 1982, 14: 127-41

62 Freiderich PW, Sanson BJ, Simionı P, et al Frequency of pregnancyrelated venous thromboembolism in anticoagulant factor-deficient women implications for prophylaxis Ann Intern Med 1996, 125: $955-60$

63 Bokarewa MI, Bremme $\mathrm{K}$, Blomback M Arg506-Gln mutation in factor $V$ and risk of thrombosis dunng pregnancy Br F Haematol 1996 92: $473-78$

64 Hellgren $M$, Svensson PJ, Dahlback B Resistance to activated protein $\mathrm{C}$ as a basis for venous thromboembolism associated with pregnancy and oral contraceptives Am f Obstet Gynecol 1995, 173: 210-15

65 Harsh DR, Mikkola KM, Marks PW, et al Pulmonary embolism and deep venous thrombosis during pregnancy or oral contraceptive use prevalence of factor V Leiden Am Heart f 1996, 131: $1145 \div 48$

$66 \mathrm{McColl} \mathrm{MD}$, Ramsay JE, Tait RC, et al Rusk factors for pregnancy associated venous thromboembolism Throm Haemost 1997, 78: $1183-88$

67 Vandenbroucke JP, Koster T, Bnet E, Reitsma PH, Bertına RM, Rosendaal FR Increased risk of venous thrombosis in oralcontraceptuve users who are carmers of factor V Leiden mutation Lancet 1994, 344: 1453--57

68 deBruin SF, Stam J, Koopman MM, Vandenbroucke JP Case-control study of risk of cerebral sinus thrombosis in oral contraceptive users who are carriers of hereditary prothrombotic conditions $B M J 1998$, 316: 589-92

69 Martınellı I, Sacchı E, Landı G, Taıolı E, Duca F, Mannuccı PM High risk of cerebral-vein thrombosis in camers of the prothrombingene mutation and in users of oral contraceptives N Engl F Med 1998, 338: 1793- 97

70 Bertına RM, Reitsma PH, Rosendaal FR, Vandenbroucke JP Resistance to activated protein $\mathrm{C}$ and factor $\mathrm{V}$ Leiden as risk factors for venous thrombosis Thromb Haemost 1995, 74: 449-53

71 Broekmans AW, Van der Linden IK, Veltkamp JJ, Bertına RM Prevalence of isolated protein $\mathrm{C}$ deficiency in patients with venous thrombotic disease and in the population Thromb Haemost 1983, 50: 350-50 (abstr)

72 Miletich IP, Prescott SM, White R, Majerus PW, Bovill EG Inhented predisposition to thrombosis Cell 1993, 72: 477-80

73 Reitsma PH, Poort SR, Allaart CF, Briet E, Bertina RM The spectrum of genetic defects in a panel of 40 Dutch families with symptomatic protein $C$ deficiency type I heterogeneity and founder effects Blood 1991, 78: 890-94

74 Nordling $\mathrm{CO}$ A new theory on the cancer inducing mechanism $\mathrm{Br} \mathcal{F}$ Cancer 1953, 7: 68-72

75 Siemiatycki J, Thomas DC Biological models and statıstical interactions an example from multustage carcinogenesis Ini 7 Epndemol 1981, 10: 383-87

76 Rostng J, Tans G, Nicolaes GA, et al Oral contracepuves and venous thrombosis different sensitivities to activated protein $C$ in women using second- and third-generation oral contraceptives $\mathrm{Br}$ F Haematol 1997, 97: 233-38

The Lancet is a weekly subscription journal For further information on how to subscribe please contact our Subscriptıon Department Tel $+44(0) 1714364981$ Fax $+44(0) 1715808175$ North America Tel +12126333800 Fax +12126333850 